Demasi, Mirko ORCID:

https://orcid.org/0000-0003-1112-8141 and Tileagă, Cristian (2019) Rhetoric of derisive laughter in political debates on the EU. Qualitative Psychology. p. 1.

Downloaded from: http://ray.yorksj.ac.uk/id/eprint/3851/

The version presented here may differ from the published version or version of record. If you intend to cite from the work you are advised to consult the publisher's version: http://dx.doi.org/10.1037/qup0000156

Research at York St John (RaY) is an institutional repository. It supports the principles of open access by making the research outputs of the University available in digital form. Copyright of the items stored in RaY reside with the authors and/or other copyright owners. Users may access full text items free of charge, and may download a copy for private study or non-commercial research. For further reuse terms, see licence terms governing individual outputs. Institutional Repository Policy Statement

\title{
RaY
}

Research at the University of York St John

For more information please contact RaY at ray@yorksj.ac.uk 


\section{Rhetoric of derisive laughter in political debates on the $\mathbf{E U}$}

Mirko A. Demasi (York St John University)

Cristian Tileagă (Loughborough University)

Correspondence concerning this article should be addressed to Dr Mirko A. Demasi, School of Psychological and Social Sciences, York St John University, Lord Mayor's Walk, York, YO31 7EX, UK. Contact: m.demasi@yorksj.ac.uk 


\begin{abstract}
This paper focuses on the argumentative role of derisive laughter in broadcast political debates. Using Discursive Psychology (DP) we analyse how politicians use derisive laughter as an argumentative resource in multi-party interactions, in the form of debates about the UK and the European Union. Specifically, we explore how both pro- and anti-EU politicians use derisive laughter to manage issues of who-knows-what and who-knows-better. We demonstrate the uses of derisive laughter by focusing on two discrete, yet pervasive, interactional phenomena in our data - extended laughter sequences and snorts. We argue that in the context of political debates derisive laughter does more than signal trouble and communicate contempt; it is, more than often, mobilized in the service of ideological argumentation and used as a form of challenge to factual claims.
\end{abstract}


Rhetoric of derisive laughter in political debates on the EU

This paper focuses on a particular type of non-verbal challenge: the use of derisive laughter. As Billig argues "a laugh can be so much more than just a laugh. In conventional terms, it is not even a laugh: it is a serious part of conversational language" (2005a, p.192). If that is the case, then one can expect laughter to play a significant part in political discourse. Arguing for a position is to also argue against the opposition (Billig, 1991), and this becomes particularly prominent in contested political discourse. Such argumentative discourse needs to be understood and analysed in the context of a "contest between criticism and justification" (Billig, 1996, p.121). Derisive laughter, we contend, can be used as a form of challenge to factual claims in political debates.

The focus of this paper is on a specific rhetorical action that laughter accomplishes in political debates, that of contemptuous ridicule or mockery, what we refer here to as derision. Following Jefferson, we treat laughter "as one among various sorts of non-speech sounds such as hammering and coughing, which occur during, and might constitute possible disruptions of, ongoing talk" (Jefferson, Sacks \& Schegloff, 1987, p. 155).

We start from the assumption that laughter is not always meant to be pleasant and decent. In Laughter and Ridicule, Billig (2005a) critiques the prevailing assumption that laughter and humour are inherently good. Disturbing and disparaging humour (Billig, 2005b; Weaver, 2015) promote hatred and violence, whilst, more generally, political jokes and political humour can create a public space for the expression of contempt towards the views of others. Contempt and derision can be used to exclude or downplay critical views of others, under the cloak of reasonableness and harmlessness. Broadcast debates on the European Union have occasioned numerous instances of scorn, contempt and ridicule towards fellow European interlocutors. Perhaps the most famous example is that of Nigel Farage's views on 
Europe in the UK whose use of ridicule in arguing against European mainstream views is notorious.

We adopt a Discursive Psychological (DP) (Edwards \& Potter, 1992) approach to understand how derisive laughter is deployed in political debates. Laughter is not constituted as an indicative of a cognitive state of mirth, but, instead, as a situated social action designed to perform very specific action (see below) which, in addition, has a strong argumentative role (Billig, 2005a). Potter and Hepburn (2010) take their analytical cue from Schegloff (2007) when they argue that one of the basic functions of laughter is to signal an understanding of what has been said": in the sense laughter is "not a separate "part" or position in the sequence" (ibid., p.25). Laughter, as something that is a part of interaction, additionally can be a display of one's stance (ibid.). If to laugh is to signal understanding of what has been said, then, by extension, to laugh is also to perform some form of 'knowledge work' in interaction. In order to begin our investigation, it is necessary to briefly cover what previous interactional studies tell us so far.

\section{Laughter and interaction}

Our analytical approach is rooted in DP (see Edwards \& Potter, 1992; Tileagă \& Stokoe, 2015). When applied to the analysis of political language, DP has evolved as representative of a distinct discourse analytical tradition (Potter, 2003) that differs markedly from what are broadly labelled as critical varieties of discourse analysis: those inspired by Foucault and psychoanalysis (Parker, 2013), linguistics (Wodak, 2009), sociolinguistics (Blommaert, 1998) and linguistic anthropology (Agha, 2007; Lempert \& Silverstein, 2012). Whereas some approaches to analysing political discourse (see, for example, Lempert \&

\footnotetext{
${ }^{1}$ A point also echoed elsewhere (e.g. Glenn, 2010).
} 
Silverstein, 2012) focus on (political) "message" as linguistic and cultural realization, the preferred focus of DP is on the action orientation of language. "Discourse is the vital medium for action", as Potter (2003, p. 791) put it. "It is the medium through which versions of the world are constructed and produced as pressing or ignorable. For social scientists the study of discourse becomes a powerful way of studying mind, social processes, organizations, events, as they are live in human affairs." (Potter, 2003, p. 791, emphasis in original)

In its analytical approach to laughter DP is closely allied with Conversation Analysis (CA) (Potter, 2010), though distinct, and there is a well-established area of CA research dedicated to studying laughter (e.g. Jefferson, 1979; Glenn, 2003; Glenn \& Holt, 2013). CA tends to focus on laughter as it unfolds in interaction, eschewing the term 'humour' and its theoretical connotations and, instead, looks to the kinds of function laughter can have in interaction. A particularly relevant aspect of our study is that laughter is not so much associated with humour as it is with some form of interactional work that is unfolding.

In CA there is recognition that laughter need not be associated with humour (Holt, 2011). Instead it is a performative; such as part of talking about one's troubles (Jefferson, 1984b), managing delicate situations in a medical setting (Haakana, 2001; Ticca 2013), orienting to institutional identities (Jacknick, 2013), or as disaffiliative actions in resisting questions in broadcast interviews (Romaniuk, 2013). As stated, it is this kind of nonhumorous, derisive, laughter that we analyse. Laughter is an ambiguous response, in that it can be affiliative or disaffiliative, and it "offers a basis for resisting an activity not overtly but subtly while allowing for continued affiliation” (Glenn \& Holt, 2013, p.17). In the context of political interviews, laughter is particularly disaffiliative when in response to a serious question, and, likewise, the interviewer not joining in on the laughter provides a similar resistance (Romaniuk, 2013). 
As Glenn and Holt argue, "broadly speaking, laughter shows up time and time again in two kinds of environments: celebrations and trouble" (2013, p.2). Our focus in this paper is on the latter. Because these broadcast political debates are "alignment-saturated" (Hutchby, 2006, p.142) - that is, discourses in these contexts are heavily oriented to the panellists having different ideological positions - one can expect laughter in these cases to be dealing with the interactional trouble of expressing contrasting views.

Communication studies have, furthermore, given considerable attention to behaviours that may be considered as 'persuasive'. In looking at such areas, they highlight how rhetoric and argumentation play a part in interaction. For example, the research on directives (e.g. Craven \& Potter, 2010; Antaki \& Kent, 2012) demonstrates how manners of speaking orient to matters of contingency and entitlement are designed to elicit specific responses from others. That is, directives can be considered 'persuasive' insofar as they are designed to produce a particular response from another person. In the context of broadcast programmes, Clayman and Heritage (2002), when analysing questions and answers, demonstrate the interplay between questions and answers. That is, interviewees, especially when facing adversarial questions, need to strike a balance between providing evasive answers while at the same time being seen to answer questions. There is a practical concern for the interviewee in how far to conform to the directives. When looking at laughter in broadcast programmes Romaniuk (2009; 2013) has looked to the evasive role of laughter, but more on this shortly.

In our data laughter is used to manage and deliver disagreement in institutionally constrained interactions, where the politicians are orienting their argument to the overhearing audience (Hutchby, 2006) as much as each other. In analysing a multi-party political debate, the adversarial role is left to the panellists and the moderators are freer to take a neutral stance (Clayman \& Heritage, 2002). In the interview format this is not the case. In the context 
of broadcast political debates there is an expectation that the panellists are advocating opposing stances (Hutchby, 2006); therefore laughter, we argue, is a means for specific argumentative actions. It is "indexical; it is heard as referring to something" (Glenn, 2003, p.48), and "as marking its referent as laughable" (Romaniuk, 2009, p.19). This act of marking something as laughable is an important function when it comes to laughter in broadcast political debates. When the panellists are debating each other, rather than answer questions to a 'neutral' presenter, it also allows for a wider range of argumentative resources for them because the image of neutrality is left with the presenter (Clayman, 1992a), freeing the debaters from trying to appear neutral. Derisive laughter is one such argumentative resource.

Much of pre-existing research into laughter, including the examples discussed so far, has provided very clear and useful accounts of the kinds of actions laughter accomplishes in interaction. However, it has been argued, there is a tendency to underplay the rhetorical functions of laughter (Billig, 2005a). CA demonstrates convincingly how laughter is performative rather than expressive of an inner mental state. It demonstrates in great detail how laughter is part of the immediate social and interactional context, action and order. When one turns to the analysis of the kinds of actions that contemptuous laughter accomplishes in multi-party political debates one needs to take into account is what derisive laughter does in argumentative terms. Laughter has a political dimension, and it can disrupt or enforce order (Billig, 2005a). So, a politician laughing at or mocking another politician is doing more than displaying a stock disaffiliative action. Political argumentation takes place through laughter, as one politician tries to enforce their stance (ibid.) - that is, their ideological stance by disrupting the argument of their opponent. An attempt is made to promote one ideological 
stance over another. The function that laughter plays in this process is that it signals an attempt to push the opponent's ideology away from the domain of 'serious' engagement ${ }^{2}$.

\section{Data}

The data is drawn from a substantial corpus of broadcast political debates on the European Union and Britain recorded between April 2012 and September 2014. All data is in English. Data is transcribed in line with a simplified Jeffersonian transcription method (e.g. Jefferson, 1984a) and seek to focus on the contested element of political discourse, to see how a politician will advocate and defend their views in the presence of those who stand for an opposing position. The focus on visual or embodied action was omitted for two reasons. First, such a focus is beyond the scope of the current argument. Second, and crucially, there is a particular practical difficulty in focusing on embodied action in broadcast programmes. Who can see what is under the control of the editors who run the programme instead of the analyst. Consequently, we have no control over what embodied action is viewable and what is not. To focus on embodied action in such a context would be to risk a skewed analysis, by way of potentially missing embodied action relevant to the interaction at hand.

The debates are all multi-party political debates, where each debate has at least one pro-EU and one anti-EU politician to argue for their respective stance. Our aim is to demonstrate some of the uses of derisive laughter in this kind of context. The examples

\footnotetext{
${ }^{2}$ To be clear, we are not claiming that the research into CA has not been fruitful. On the contrary it provides a sound platform from where to carry out a DP analysis of laughter, accounting for its rhetorical and argumentative function. Likewise, we are not claiming that all instances of laughter in broadcast political debates are derisive in nature. Laughter is a subtle and, sometimes, elusive phenomenon.
} 
included in the analysis are pervasive, as far as laughter in broadcast political programmes are concerned, and typical of the way derision was accomplished by way of laughter ${ }^{3}$.

Our aim is twofold. First, we focus on laughter in a novel context: that of broadcast political debates as multi-party interactions. While work on broadcast political programmes is by and large well established (e.g., Clayman \& Heritage, 2002; Hutchby, 2006; Romaniuk, 2009 ; 2013) they have not always focused on multi-party interactions in the debate format. The debating politicians have more interactional freedom to challenge their opponents in a broadcast political debate, and they act on it. This is because, as stated, in broadcast political debates the moderator is not the one who does the debating, and there is a lesser conflict of institutional roles. Not having to balance an image of neutrality while pursuing an ideological agenda, as might be the case for moderators in broadcast interviews, the adversarial role is left to the panellists, giving them more freedom to express disagreements (Clayman \& Heritage, 2002). Our focus is on a type of contested political discourse and laughter's argumentative role in relation to this. The analysis aims to capture precisely this - how opposing positions are advocated and undermined with the use of laughter in a multi-party setting.

Second, factual accounts are crucial for politicians to put forth their argumentative position in the debate - and laughter has a part to play in this. These accounts that a politician produces do argumentative work and are used to undermine other accounts. As stated, arguing for and arguing against a specific viewpoint are often done jointly (Billig, 1991; 1996). Much of arguing against can be done by way of challenging the 'facts', 'states of affairs', and so forth, of what a politician's 'ideological' opponent is claiming (see Demasi, 2019). Here we focus on the argumentative work that derisive laughter accomplishes in

\footnotetext{
${ }^{3}$ This is not to say that there were no other ways of accomplishing derision. The present analysis is concerned with derision that takes place in conjunction with laughter.
} 
broadcast political debates. We show that laughter can, for example, precede potentially offensive remarks or downplay complaints that may otherwise come across as too strong (Billig, 2005a). Potentially, laughter, then, can provide a debater with means of advancing and challenging positions in ways that may otherwise be sanctioned.

Put simply, to laugh in a political debate is to do argumentative work. Presently there is relatively little research into laughter in a political setting (but see Romaniuk, 2009; 2013). Furthermore there is some research on multi-party interactions and laughter (Osvaldsson, 2004), but studying it in the context of broadcast political debates is still under-represented in the literature. The aim of our analysis is not to provide a representative overview of laughter in broadcast debates, but, rather, to describe a particular discourse phenomenon. Nor are we claiming that all instances of laughter are derisive, or that all cases of derisive laughter carry the same rhetorical function. We analyse the rhetorical function of laughter and derision - we illustrate what kinds of actions laughter can constitute and how actions accomplished through derisive laughter are used to challenge issues of 'factuality'.

\section{Reflexive Statement}

This research stems from the $\mathrm{PhD}$ thesis of Mirko Demasi, under the supervision of Cristian Tileagă. Our interest in studying political debates on the European Union especially the focus on discursive strategies, such as derisive laughter discussed here, of argumentation in political debates - has developed organically out of the first author's doctoral research along two strands. First, an interest in understanding the social organisation of political discourse in politically uncertain times. Namely the contentious relationship between the UK and the EU, Brexit and how politicians argue about these. Political debates 
on the EU provided abundant data and a fertile ground for discursive psychological analysis. When the data collection began, in early 2012, the EU was already a contested topic in British media and political discourse; with the topic of should UK leave the EU given considerable airtime. Second, a matter of personal relevance as EU citizens. As people with continental European backgrounds living in the UK it was also a topic of personal interest and concern for us, not knowing how Brexit will influence our position as people living in the UK.

In DP, the issue of reflexivity is embedded into the analysis. The aim is to analyse the data in terms of how the participants orient to the interaction (Potter, 2010), interaction is "highly resistant to faking" (Potter, 2012, p. 445) and to report it in a manner that opens the analysis up to scrutiny by the reader (Potter, 1988, as cited in Potter, 2010). The issue of presenting data is a more complex one. The data under analysis was selected from the public domain, is available and analysable for any researcher and, on that account, arguably has less issue with 'reactivity' (Potter, 2012) than other methods of data collection. However, the picking and presenting of the data has been necessarily selective to present what we believe is the strongest case for our analysis. Our intent has been to demonstrate that laughter plays a rhetorical role in political debates, and in a way that it should be treated seriously, and we have opted for extracts that we consider to be the most effective demonstrations of this.

The importance of understanding EU debates has now, in light of the 2016 Brexit referendum, become more pertinent than ever, we hope not only for scholars living in the UK and EU. We hope that colleagues in the wider qualitative research methods community in the US and elsewhere will appreciate what motivated us to research these kinds of concerns in the first place. To analyse and explicate how these debates (so prevalent in UK contemporary 
media) unfold, to illustrate some of their rhetorical stakes, is, for us, not only an area of scholarly interest but one of personal concern as an uncertain future awaits the UK.

\section{Analysis}

Past research has demonstrated laughter to be a common resource used by speakers: sometimes it performs resistance of some kind (Romaniuk, 2009; 2013), other times it can manage the expression of undesirable news (Haakana, 2001), or, on other occasions, it can be used to smooth over otherwise argumentative moments (Osvaldsson, 2004). By focusing on derisive laughter, we contend that a politician's laughter can be used to signal more than trouble; we show how derisive laughter, can be, more than often, mobilised in the service of ideological argumentation and used as a form of challenge to factual claims. We analyse laughter in two conversational environments: in extended sequences (of laughter) and in sequences with displays of laughter micro-particles in the form of snorts.

\section{Derision in Extended Laughter Sequences}

The first example of extended laughter is from a debate between Nigel Farage of the UK Independence Party (UKIP) and Gay Mitchell of the Fine Gael party.

\section{Extract 1}

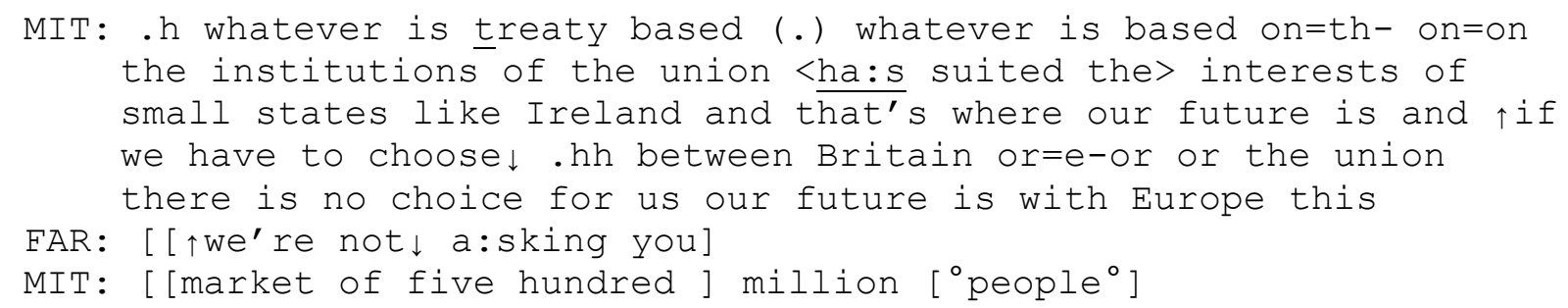




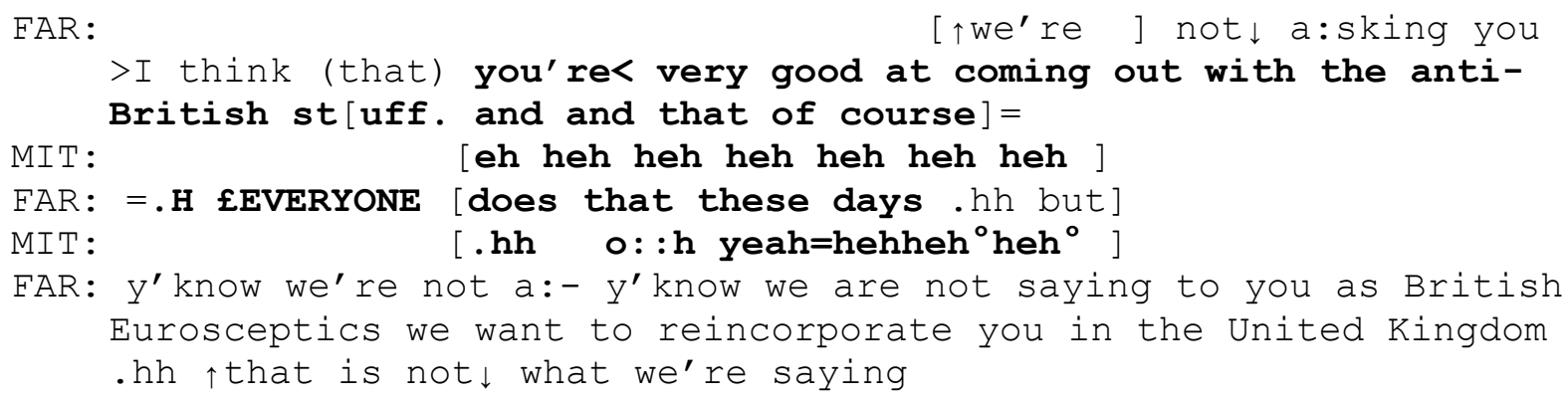

In this extract Farage is claiming that Mitchell is anti-British (lines 10-11, 13), with an audible smiling voice when the word "everyone" is said on line 13. At lines 12 and 14 Mitchell replies with a long slow laughter in overlap with Farage's claim. Note that Farage is at least in part enabled by his institutional role to make such assessments. As a politician expected to argue for a particular position, he is not bound by an institutional restriction to display neutrality in the same manner a moderator would be (Clayman \& Heritage, 2002). Mitchell responds with laughter and an ironic agreement. This can be seen as marking of Farage's comment as laughable. Such stretches of laughter do not occur at random; rather they seem to occur at places where a criticism is in need of modulating in some manner (Clayman, 1992b; Billig, 2005a; Romaniuk, 2009). As such, Mitchell's response marks a clear stance toward what Farage is saying - the implication is that Farage's claim is laughable, and the laughter serves to undermine it. This instance may seem, on the surface, a humorous occasion. However, a very serious argument is the bone of contention. What is laughed at is not a joke; the target of the laughter is a serious claim about bias. The implicit claim of bias is itself implicitly derided.

Mitchell's laughter here demonstrates his stance - that of an implicit critique of Farage's claim - but it also demonstrates an understanding (Potter \& Hepburn, 2010) of the matter at hand. In order to demonstrate one's stance, the implicit message is that one knows what one is displaying their stance on. In other words, Mitchell's laughter is designed to show Farage, and the viewers, that not only does he know what is said of him, but he also 
uses this display of knowledge to treat it as something that is laughable. It undercuts the factuality of Farage's assertion. Furthermore, he does so from an epistemically upgraded stance - presenting oneself as the one who 'knows more' than their opponent. Heritage and Raymond (2005) point out that the order of the actions of confirming and agreeing to someone's utterance does demonstrative work on who 'knows more'. In responding to someone, if the action of agreeing comes after the confirmation then it comes from an upgraded stance ${ }^{4}$. This is because the action of confirming is delayed in order to display one's ‘knowledge status' first (ibid.). We see similar work done by Mitchell here, when he laughs before ironically agreeing with Farage.

Not only is the agreement delayed by the use of laughter (Romaniuk, 2013), but it is done in a context of things to be laughed at, which creates an ironic context to his agreement. The ironic context implies that Mitchell's agreement is not to be taken at face value, this being particularly relevant in a televised debate (Kotthoff, 2003), and is further emphasised by the absence of confirmation by Mitchell. Romaniuk (2013) highlights that in laughing at the interviewer's question before it is complete, the interviewee avoids answering the question outright "since that would require her to confirm the truth of those unfavourable propositions; instead, it addresses the content of the question preface" (p.213). Volunteered laughter in the face of a serious question is disaffiliative. The responsive aspect of laughter applies here. In other words, the laughter acts "as an implicit commentary on the question, undercutting its legitimacy" (ibid., p.205). In laughing at Farage's claim Mitchell is challenging the seriousness - and, by implication, the truthfulness - of the assertion. Overall, Farage has used a hearably ironic approach as means of making a derisive assessment, by suggesting that Mitchell has an anti-British bias rather than a reasoned pro-EU position, as a epistemically upgraded stance. See Heritage and Raymond (2005) for a more detailed discussion. 
means to undermining Mitchell's pro-EU stance, and Mitchell has resorted to a similar method to brush it off as a point of any serious discussion.

In the extract below, the laughter is more one-sided and explicitly derisive than in the example above. Here, Nigel Farage's laughter can be heard to overlap Nick Clegg's claim of the EU acting in favour of the British people and criticising UKIP. The context to Clegg's claim is that he frames it as an example of why the EU matters for (policing in) Britain. This in turn does the wider work of arguing in favour of the EU.

Extract 2

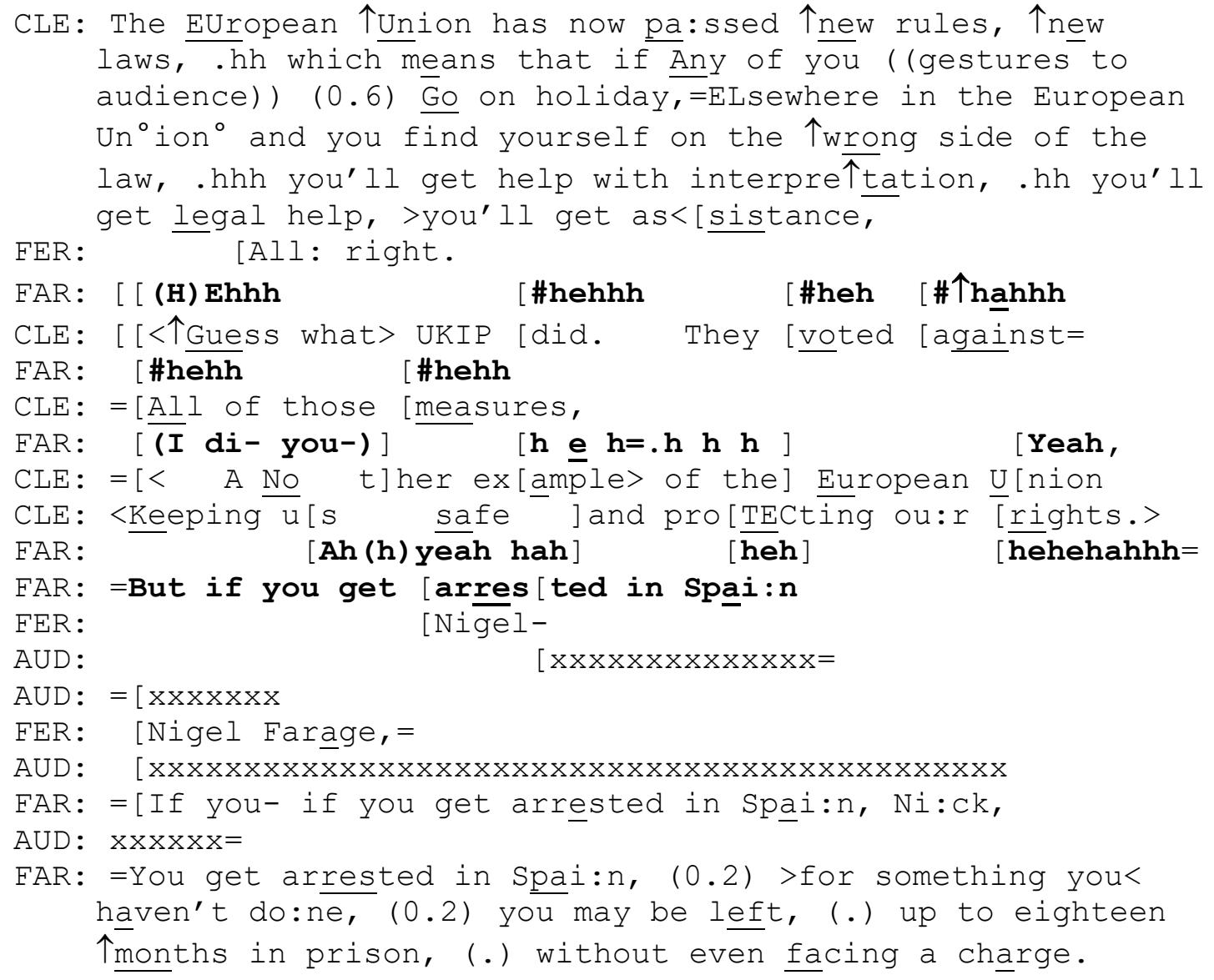

Of interest in this extract are Farage's persistent laughter particles, which are observed on lines 9, 11, 13 and 16. The laughter particles on lines 9, 11, 13 and the middle laughter particle on line 16 are distinct from each other and in notable overlap with Clegg's 
talk. Farage's first laughter on line 8 would appear to be in response to Clegg's point about EU rules done in favour of people. The subsequent laughter seems to orient to Clegg's assertion (lines 9-11). These go over Clegg's talk and are fairly evenly paced in doing so. The patchiness of the laughter, in contrast with Mitchell's laughter in Extract 1, gives it an air of artificiality, especially as they become louder after Clegg begins his critique of UKIP. They seem to be done in overlap as a way of stance display and competitiveness to be heard (Schegloff, 2000) as oriented towards the audience. Although it may be difficult to pinpoint what exactly the laughter orients to, it is worth pointing out that in the overall extract the laughter follows and overlaps points that are at the very least potentially damaging for Farage's 'ideological' stake and interest in the debate.

Looking at orientations to factuality here Farage is displaying himself as knowledgeable of the matter at hand and treating Clegg's talk as something laughable. The initial laughter particle (line 9) is crucial in this, as it seems to label Clegg's claim as laughable. As suggested the absence of confirmation or agreement in this instance by Farage positions him as 'more knowledgeable', as the act of confirming is replaced with the act of treating Clegg's claim as laughable. The laughing implies that there is something missing, off point, regarding the factuality of Clegg's claim. It is possible that other types of work or resistance may have taken place, as it seemed the moderator was about to hand the floor over to Farage (line 8). This, however, did not occur as Clegg continues his assertion, marking it as explicitly anti-UKIP. In this immediate interactional context to keep laughing seems to be akin to a refusal to concede the floor and, crucially, the critique in favour of Clegg. Additionally the persistent presence of laughter particles on lines 9, 11, 13 and 16, aside from performing argumentative work, are can be seen as intrusive interruptions (Murata, 1994), making it harder for Clegg to continue his point and for the audience to follow it. 
Farage is treating Clegg's claim as laughable; his laughter not only displays his stance to the audience but is also derisive of Clegg. His laughter glosses over a large segment of Clegg's talk and its very presence, and delivery, ridicules and undermines Clegg's claim. It is as if Farage's laughter is seeking to 'discipline' Clegg (Billig, 2005a), to put him down, on account of his, seemingly, 'erroneous' position. Farage's rebuttal suggests that Farage is looking for a reason for the laughter and in this way mocks Clegg's position: there is no need of the EU because Britain already has a common law, which, by the by, is better than those of other European countries. By framing himself as one capable of ridiculing and correcting Clegg, Farage frames himself as more knowledgeable than Clegg on the matters of the EU.

Extended laughter, then, in contexts such as these, can provide a tool for politicians arguing against each other. The ironic context created by laughter allows politicians to put out and challenge assertions that might otherwise be disapproved or sanctioned in some manner. In addition, laughter can be highly interruptive, derisive, and portrays the laugher as being the one who 'knows more' in order to downplay or challenge the object of laughter. It does not always matter so much that the politicians put out their assertions in a non-serious manner or that the moderator interjects - this kind of needling does not go unheard. The audience and the other debater have already heard the accusation, the "damage is done", and the serious work of political argumentation carries on.

\section{Snorts}


This section focuses on another specific means of accomplishing derision in debates: snorts $^{5}$. A snort, according to the Oxford Dictionary of English is "an explosive sound made by the sudden forcing of breath through the nose... [to] express indignation or derision”. The notable feature of this pervasive phenomenon in our data is that these explosive sounds seem to display more hostility and are being positioned at very relevant junctures in the debates.

Importantly, the accepted definition of a snort allows us to make a link between snorts and a display of derision. Snorts are not commonly produced behaviours in political debates, nor are they analysed extensively in the conversation and discursive analytic literature. Yet, at least in our data, they seem to display a very distinct type of social action, taking place at specific points in these debates, which warrants a closer analytical look.

\section{Extract 3}

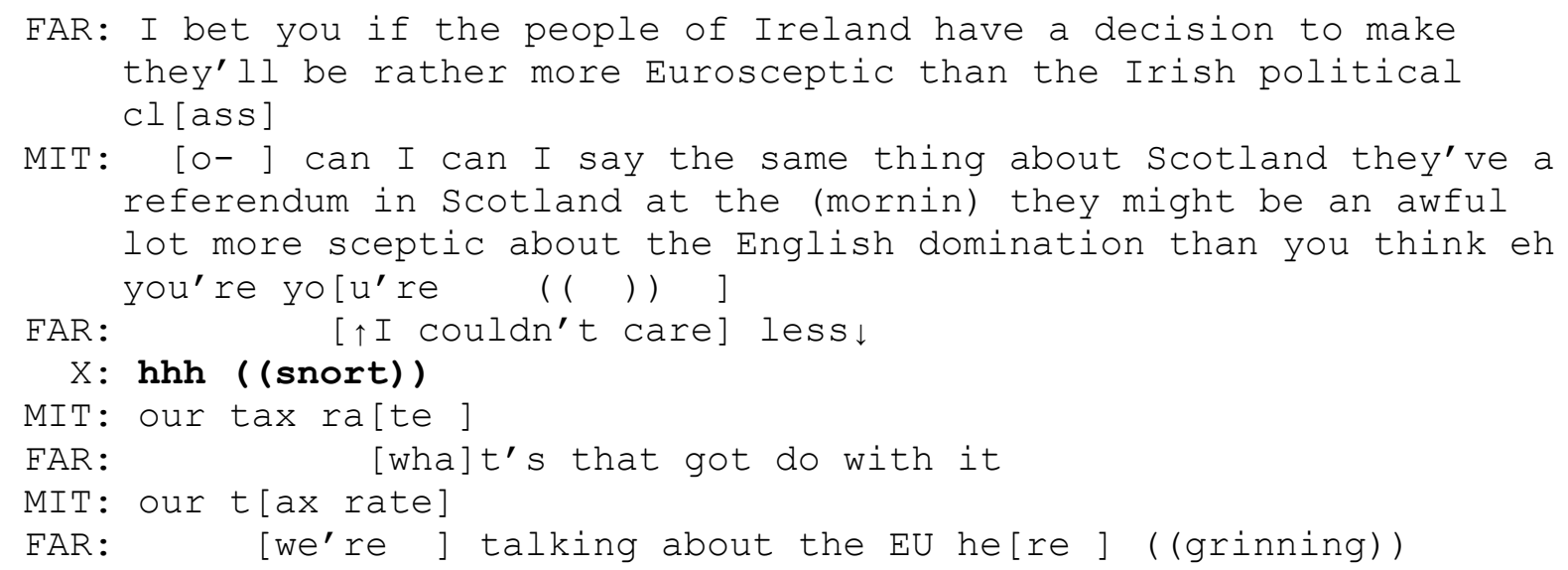

There is a snorting sound on line 9 from an unspecified speaker in clear response to Farage's declaration of indifference. The snort seems to be providing a disparaging response to Farage's “I couldn't care less" (line 8). Such an open claim of indifference, especially by a politician on a public platform, is, arguably, unexpected. The snort orients to Farage's claim as risible and contextually inappropriate; it is likely to signify, amongst other things, 'trouble'

\footnotetext{
${ }^{5}$ Snorts were transcribed with some difficulty, hence the addition of the description in order to make the transcript clearer.
} 
in the interaction at hand. The snort signals indignation to a claim of (political) indifference in a context of debate, controversy and vested interest. It can be a way of signalling the need to return to the norms of the interaction at hand. Trouble-related laughter can be a "resource for aligning, modifying actions, and mitigating meanings" (Glenn \& Holt, 2013, p.2). In this instance, because the snort on line 9 comes immediately after Farage's claim of indifference, it can be seen to respond to the claim. Because of its close following of the "I couldn't care less" it arguably looks to mitigate the statement and the direction it might take.

One of the common uses of a snorting response is that of signalling indignation, as we have seen. However, snorts can also be used, more radically, as an attempt to shut down the course of an interaction. This is not to say that snorts will bring to an end the course of an interaction, but, instead, they can signal a politician's stance on matters of interest that will not be responded to. Such a response sends an unambiguously disaffiliative response. A snort is an orientation to treating the preceding utterance as insufficient - much in the way other work on laughter has demonstrated (e.g. Potter \& Hepburn, 2010; Romaniuk, 2013) - in some manner, thus avoiding a conforming response to it. In the following example, all three snorts by Dan Jørgensen (a Danish MEP), we see how there is little response to snorts, and how providing a minimal response by way of a snort does enough interactional work to inform the other debaters and the overhearing audience of the snorting politician's stance.

\section{Extract 4}

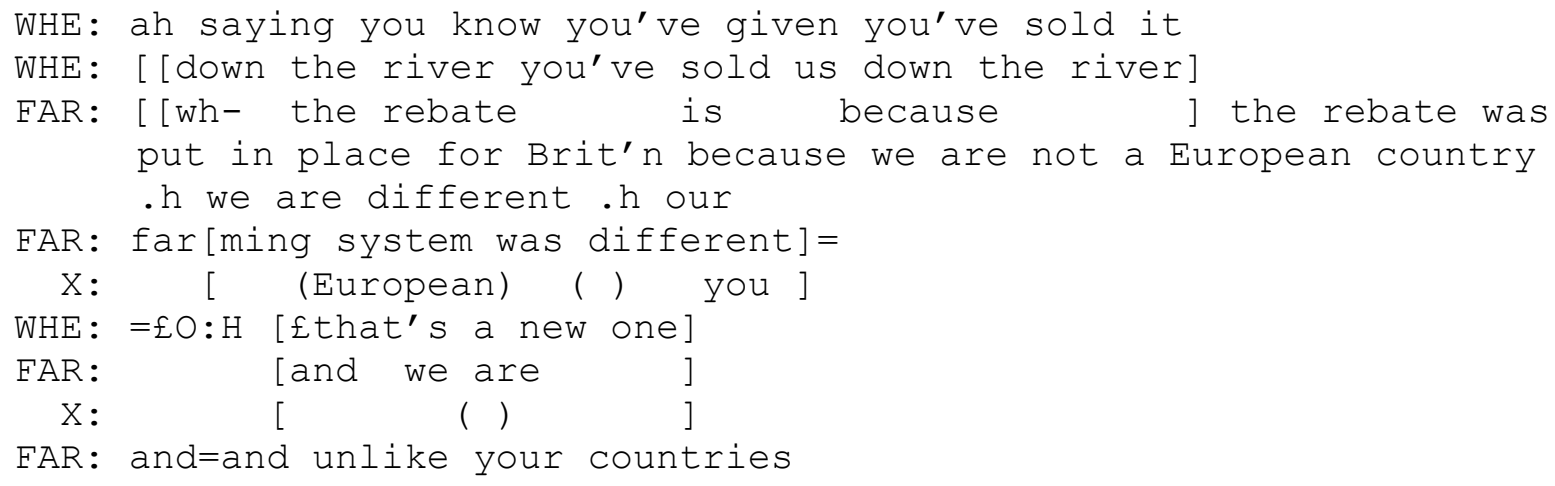


12 JøR: okay

13 FAR: unlike your countries. we're a globa[l nation]

14 JøR:

$15 \quad(.2)$

16 FAR: we do a bigger proportion of=of our trade and our business .h

17 with the rest of the world than <any other> European country

18 JøR: [ [ ahhh ] ((snort))

19 FAR: [ [we always] have and=and=and my hope is that we'll go on doing

20 that

21 WAT: $={ }^{\circ}$ Den [mark is a glo]bal nation? ${ }^{\circ}$

22 FAR: [so that's why]

23 WAT: Germany is [a global nation?]

FAR: [no Germ ] any

FAR: is not a global natio[n compared (with)] compared with

WHE: [the Netherlands?]

FAR: Britain. (.)

\section{((35 lines of transcript omitted))}

61

62

63

64

65

66

67

68

69

70

71

72

73

74

75

76

77

78

79

80

81

82

83

84

85

86

87

88

89

90

91

92

93

94

$\mathrm{J} \varnothing \mathrm{R} \cdot$

[how d- how] do I tell my

constituency that we are net payers (as) well except m- every

Dane pays three times as much to the EU as the

JøR: Bri[tsh ( ) ]

FAR: [(well) if you're (being)]

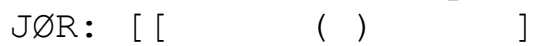

FAR: [ [if you're being] a worse deal than us

JøR: we ['re (def-) ]

FAR: [that's a comp]arison of misery isn't it

JøR: ah $[\mathrm{h}: \quad]$ ( (snort))

FAR: [and yo]u should be arguing that your people shouldn't be paying much money into this $\uparrow$ either $\downarrow$

JøR: no what I am arguing is (.2) that (.2) it's too simple a way of putting it (.2) what you need to see is okay how much does the the: the st-European Union and (mat-)ordinary people and Europe FAR: very li[ttle they] hate it

JøR: $\quad[\uparrow i t \uparrow m a t t e r s$ a lot $\downarrow]$

JøR: we make common rules [ ( ) ] (environments)

FAR: [they hate it]

JøR: we make common rul- [ (well) one of the ] reasons

FAR: [they voted against it]

JøR: some of them hate it is because

$(.2)$

JøR: people li[ke you ( ) some of the]

FAR: [well your country said no in] a referendum to it

JøR: listen.

FAR: twice [TWICE

JØR:

$\left[\begin{array}{ll}\text { [ } & (\text { ) }\end{array}\right.$

WHE : $\quad[l e-$ let let let NI:- ]

WHE: let Da [n finish the ]

JøR: [ ehheh ] ( (snort))

WHE: [ [sentence then I'll come to the end]

FAR: [ [come on we've been ( ) arguing the Da]nish people they $\uparrow$ keep saying $\mathrm{NO}: \downarrow$ 
Jørgensen - in lines 19, 70, and 92 - snorts in response to Farage's assertions. Each is discussed in turn. The first snort is in response to Farage claiming that Britain is a global nation unlike Denmark, which Jørgensen, as a Danish MEP, represents. Specifically, it is Farage's justification of this claim that Jørgensen responds to with a snort. The original claim is met with silence (line 15), possibly suggesting some resistance by Jørgensen. The interaction seems to indicate that Farage did not concede the floor at this point but intends to continue his claim. It is nonetheless a notable point of transition (Sacks, Schegloff \& Jefferson, 1974), where Jørgensen could have attempted to respond or take the floor. This problem is further highlighted in that Jørgensen is observably listening to Farage (lines 12, 14, his gaze directed at Farage) up until that point. Jørgensen's non-response on line 15 and his snort on line 19 constitute a similar action. Farage has addressed Jørgensen directly and has claimed that Britain is a global nation whereas other European nations ${ }^{6}$ are not (lines 4-6, $9,11,13)$. First, by providing no or minimal responses, Jørgensen is avoiding a direct orientation to Farage's claims and thus avoids treating it as legitimate. At first, he does not respond to Farage (line 15), but when Farage provides a justification for his assertion (lines 16-18), a persistent silence from Jørgensen would do little by way of challenging Farage. Thus, a snort (line 19) provides a response that is enough to portray his stance and to do the 'knowledge work' of both displaying understanding and treating Farage's position as not only laughable but also to be derided. Second, Farage and Jørgensen, not only as politicians of different parties but also as two people with different nationalities, in this debate arguably have different "epistemic domains"7 (Kamio, 1997, as cited in Heritage, 2012) and primacy to their respective domains. Farage's assertion and his subsequent justification of it is rooted in

\footnotetext{
${ }^{6}$ It is not clear whether Farage means Denmark or non-British nations more generally, but at this stage he is visibly addressing Jørgensen who, as such, is treated as the representative of the 'non-British' group.

${ }^{7}$ The case under analysis here is also an indicative of how seamlessly switches between epistemic domains can take place. For much of these debates, Farage speaks as an 'EU expert' but in this instance he switches to that of a British one. Later in the extract, line 65 onwards, he speaks again as an EU expert.
} 
the nature of Britain. The 'knowledge' that is talked about relates specifically to his country (e.g., line 16) - Farage’s epistemic domain and, significantly, not Jørgensen’s. Notably, in order to do this Farage needs to address Jørgensen instead of Watson or the presenter who are both British nationals. This reinforces that Farage, though talking of European countries in general, is speaking as a British person rather than as an "EU expert". This is further reinforced when looking at the fact that Wheeler (the presenter) and Watson challenge Farage (lines 8, 22, 24, 26, 27) instead of Jørgensen. It is to these challenges when other British speakers challenge Farage's claim that we can observe him responding to on line 25. Jørgensen on the other hand could not provide an "unqualified" challenge of Farage's claims about Britain in the way that Watson and Wheeler, as British people, did. The insertion of a snort in lieu of a more spelled out counterclaim is telling; Jørgensen's derision instead of a more spelled out challenge constitutes an orientation to the domain of 'Britain' as one that is Farage's. In this light, a minimal derisive laughter, in argumentative terms, could well be the strongest rhetorical response that Jørgensen can offer. The challenging of Britain's nature is left to fellow Brits.

On line 70, we see the second snorting response from Jørgensen. The snort is in response to Farage's somewhat hyperbolic claim on lines $65,67,69$. The snorting response does much of the same resisting work as mentioned above - not treating the assertion as legitimate, treating the claim as laughable, beyond the norms of the interaction and so on. Notably, this time the snort seems to be responding to the hyperbolic element of Farage's assertion, rather than Farage's justification of his assertion. Jørgensen responds to Farage’s justification on lines 71-72 in a manner that not only does 'epistemic work' in the argumentation, much in the manner discussed so far, but there is also an additional element of deontic resistance (Stevanovic \& Peräkylä, 2012) one lines 73-74. In replying by stating what he is doing, Jørgensen resists Farage's imperative as to what he should do. He is able to do 
this as he has the primary access to speak of his own intentions, and because deontic authority, much like epistemic domains, is heavily contextual (ibid.). Also, by doing so, Jørgensen sidesteps the issue of having to address the cost of EU membership for Danish citizens. The snort, then, is the beginning of resistance work to Farage's assertion that the EU is too expensive and a source of misery. The very descriptive term "misery" is treated as laughable, and with hostile derision, in order to do the work of pushing it away from the debate. Jørgensen’s verbal part of resisting not only seeks to repel the argument made by Farage, but also what Jørgensen should do. In this sense, we see not only ideological conflict here but also that of 'power': "epistemic authority is about knowing how the world 'is', deontic authority is about determining how the world 'ought to be'" (Stevanovic \& Peräkylä, 2012, p.298).

The final snort comes at line 92 . Between lines 77 and 94 there is a great deal of overlapping talk. Much of it is interruptive in nature where Farage is speaking simultaneously with Jørgensen. Looking at the 'knowledge work' that takes place, it is a strong push into Jørgensen’s domain by Farage, as he speaks of the Danish people ${ }^{8}$. On line 83, Jørgensen attempts to begin a claim that some people hate politics because of people like Farage. However, before he gets to finish, Farage overlaps by stating that the Danish people voted 'no' in a referendum. It is not clear to which referendum Farage is referring to, nor does it need to be in order to understand the action Farage's utterance is doing. With such a claim, enough argumentative work has been done to suggest that the anger of the Danish people is related to their internal political behaviour, and not politicians such as Farage. By offering an alternate category for the cause of the Danish people - their voting 'no' in a referendum rather than politicians such as Farage - the accountability (Tileagă, 2010) of the Danish

\footnotetext{
${ }^{8}$ Judging by the preceding talk, in relation to Jørgensen's question on lines 61-64, there is strong indication that the "they" used by Farage refers to the Danish people.
} 
discontent is placed with Jørgensen who, in the context of this debate, represents the pro-EU 'ideology'.

The examples of snorts above show different interactional contexts in which they can be used, and the kind of work that they do. They show how derision can be a very useful argumentative tool for politicians especially when mobilized in the service of ideological argumentation and contributing to the management of contested political discourse in broadcast debates. Derision can serve as a subtle form of factual counterclaim insofar as it is designed, and carefully positioned, to challenge and to undercut the legitimacy of a factual claim. However, it is also a unique kind of counterclaim in that it does not provide direct challenge of the 'facts' or 'knowledge' of the opponent's claim but, instead, demotes them to the domain of things that are laughable, therefore not serious or relevant, and paints a picture of the opponent as one not in possession of the relevant 'facts' or 'knowledge'. Thus the 'knowledge battle' that takes place here is not only by upgrading in the manner that is done in normal conversation; a politician also fights for epistemic primacy by downgrading their ‘ideological’ opponent.

\section{Conclusion}

This article has considered some uses of derisive laughter in multi-party broadcast political debates. It has identified a rhetorical orientation to and use of laughter. This has been considered in two particular conversational environments: extended laughter sequences and sequences with displays of laughter micro-particles in the form of snorts. In the first part of our analysis we discussed how laughter can be used to signal a politician's stance in a debate. We showed how extended laughter was used to show political disagreement and how it was 
used to disrupt the flow of a political debate by downplaying the seriousness of a factual point.

We then turned to look at snorts and explored how they are associated with indignation and derision. We showed how snorts were interactionally positioned to fulfil a key rhetorical role: that of deriding ideological opponents. In terms of its positioning, a snort can be a challenge on its own or it can precede a more spelled out challenge. It can be used to challenge a claim rooted in a specific epistemic domain, or to mark something, such as hyperbolic claims, as inappropriate or irrelevant. Snorting can be used as a non-verbal counterclaim tool that seeks to undermine and challenge the 'factuality' of the claim it targets.

What we found, in line with previous research, is that "in general, the transition from talk to laughter to talk is done in orderly fashion" (Jefferson et al., 1987, p. 156). However, we also can see how politicians engage in competitive overlapping talk with derisive laughter being used to punctuate challenges and score political points. We found that derisive laughter did not follow the classic assumption that laughter should be considered "an activity to which one participant may invite another or others - an invitation which may be accepted or declined" (Jefferson, 1979, p. 80). However, laughter was, nonetheless, a sequentially implicative object in interaction. In their discussion of expanded affiliative sequences Jefferson et al. have argued laughter can occur as an "accessory activity, performed as a way to arrive at some specifiable outcome" (1987, p. 159). In political debates, seen as primarily as disaffiliative sequences, we see how laughter is performed as a way to arrive at delivering a challenge and/or ridiculing a political opponent.

A running theme in our analysis has been that derisive laughter serves both an interactional and ideological function. On the one hand, it is used to signal the laughing 
person's stance regarding their 'ideological' opponent or their claim. To laugh at someone in a political debate is to imply who-does and who-ought-to know better. Laughter, especially in extended sequences, can function as an upgrade that position the person laughing as the one who 'knows more/better'. On the other hand, derisive laughter accomplishes contempt from a position of reasonableness whilst excluding or downplaying competing or opposing views.

Derisive laughter fulfils a crucial argumentative role. Not just as laughter in and of itself, as Billig (2005a) has already shown, but as social action in the context of ideological political debates.

Derisive laughter can serve as a sort of counterclaim that demotes the opponent's claim to something that is not worthy of serious debate, suggesting to the overhearing audience that the target of the derision is someone who does not have relevant 'facts' of the matter at hand. In our data we have seen how derisive laughter occurs at points where the laugher is facing potential criticism; we have also shown how derisive laughter serves a strong method of resisting the said criticism. We do not expect that the findings presented in this paper will neatly apply to other multi-party contexts, nor do we make claims of generalisability. What we set out to do is to illustrate and discuss the rhetorical functions of a particular discourse phenomenon. We acknowledge that derisive laughter can have other functions too and that it not only manifests itself in political discourse. Comparative analyses of the use of (derisive) laughter across a variety of interactional contexts, other than political debates, may point to more of its features, forms, and styles.

However, what we have found analysing political debates we believe to be a robust set of phenomena of key importance to beginning to understand how derision works in contexts of justification and criticism. Our findings should be of use not only to discursive 
psychologists and conversation analysts, but also those with an interest in language, politics and identity in the wider academic community.

Broadcast political debates are not designed for comedic purposes, yet they contain laughter. Our findings suggest that laughter is used across the political spectrum. Therefore, derisive laughter is not a rhetorical outlier. Previous research tells us laughter can be a nonhumorous part of everyday conversations; our analysis takes this a step further in arguing that one should accord it a serious part in the study of political discourse. 


\section{References}

Agha, A. (2007). Language and Social Relations. New York: Cambridge University Press.

Antaki, C. \& Kent, A. (2012). Telling People What to Do (and, sometimes, why): Contingency, Entitlement and Explanation in Staff Requests to Adults with Intellectual Impairments. Journal of Pragmatics, 44(6-7), 876-889.

Atkinson, J.M. \& Heritage, J. (1984). Structures of Social Action - Studies in Conversation Analysis. London: Cambridge University Press.

Billig, M. (1991). Ideology and Opinions: Studies in Rhetorical Psychology. London: Sage.

Billig, M. (1996). Arguing and Thinking - A Rhetorical Approach to Social Psychology, $2^{\text {nd }}$ Ed. Cambridge: Cambridge University Press.

Billig, M. (2005a). Laughter and Ridicule - Towards a Social Critique of Humour. London: Sage.

Billig, M. (2005b) 'Comic racism and violence', in S. Lockyer and M. Pickering (Eds.) Beyond a Joke. The Limits of Humour (pp. 25-44). Basingstoke: Palgrave-Macmillan.

Blommaert, J. (1998). Debating Diversity: Analysing the Rhetoric of Tolerance. London: Routledge.

Clayman, S.E. (1992a). Footing in the Achievement of Neutrality: The Case of Newsinterview Discourse. In Drew, P. \& Heritage, J. (Eds.), Talk at Work: Interaction in Institutional Settings (pp.163-198). Cambridge: Cambridge University Press.

Clayman, S.E. (1992b). Caveat Orator: Audience Disaffiliation in the 1988 Presidential Debates. Quarterly Journal of Speech, 78(1), 33-60. 
Clayman, S. \& Heritage, J. (2002). The News Interview: Journalists and Public Figures on the Air. Cambridge: Cambridge University Press.

Craven, A. \& Potter, J. (2010). Directives: Entitlement and Contingency in Action. Discourse Studies, 12(4), 419-442.

Demasi, M.A. (2019). Facts as Social Action in Political Debates about the European Union. Political Psychology, 40(1), 3-20.

Drew, P. \& Heritage, J. (1992). Talk at Work: Interaction in Institutional Settings. Cambridge: Cambridge University Press.

Edwards, D. (2005). Moaning, Whinging and Laughing: The Subjective Side of Complains. Discourse Studies, 7(1), 5-29.

Edwards, D. \& Potter, J. (1992). Discursive Psychology. London: Sage.

Glenn, P. (2003). Laughter in Interaction. Cambridge: Cambridge University Press.

Glenn, P. (2010). Interviewer Laughs: Shared Laughter and Asymmetries in Employment Interviews. Journal of Pragmatics, 42(6), 1485-1498.

Glenn, P. \& Holt, E. (2013). Studies of Laughter in Interaction. London: Bloomsbury Publishing Plc.

Haakana, M. (2001). Laughter as a Patient's Resource: Dealing with Delicate Aspects of Medical Interaction. Text, 21(1/2), 187-219.

Heritage, J. (2012). The Epistemic Engine: Sequence Organization and Territories of Knowledge. Research on Language and Social Interaction, 45(1), 30-52. 
Heritage, J. \& Clayman, S. (2010). Talk in Action. Chichester: Wiley-Blackwell.

Heritage, J. \& Raymond, G. (2005). The Terms of Agreement: Indexing Epistemic Authority and Subordination in Talk-in-interaction. Social Psychology Quarterly, 68(1), 15-38.

Holt, E. (2011). On the Nature of "Laughables": Laughter as a Response to Overdone Figurative Phrases. Pragmatics, 21(3), 393-410.

Hutchby, I. (2006). Media Talk - Conversation Analysis and the Study of Broadcasting. Maidenhead: Open University Press.

Jacknick, C. (2013). “Cause the Textbook Says...”: Laughter and Student Challenges in the ESL Classroom. In. Glenn, P. \& Holt, E. (Eds.), Studies of Laughter in Interaction (pp.185-200). London: Bloomsbury Publishing Plc.

Jefferson, G. (1979). A Technique for Inviting Laughter and its Subsequent Acceptance/Declination. In Psathas, G. (Ed.), Everyday Languages: Studies in Ethnomethodology (pp.79-96). New York: Irvington.

Jefferson, G. (1984a). Transcription Notation. In Atkinson, J., \& Heritage, J. (Eds.), Structures of Social Interaction (pp. ix-xvi). New York: Cambridge University Press.

Jefferson, G. (1984b). On the Organization of Laughter in Talk about Troubles. In Atkinson, J., \& Heritage, J. (Eds.), Structures of Social Interaction (pp.346-369). New York: Cambridge University Press.

Jefferson, G., Saks, H. \& Schegloff, E. (1987). Notes on Laughter in the Pursuit of Intimacy. In Button, G. \& Lee, J.R.E. (Eds.), Talk and Social Organisation (pp.152-205). Clevedon: Multilingual Matters Ltd.

Kamio, A. (1997). Territory of Information. Amsterdam: John Benjamins. 
Kotthoff, H. (2003). Responding to Irony in Different Contexts: On Cognition in Conversation. Journal of Pragmatics, 35(9), 1387-1411.

Lempert, M. \& Silverstein, M. (2012). Creatures of Politics: Media, Message, and the American Presidency. Bloomington: Indiana University Press.

Lockyer, S., \& Pickering, M. (2005). Beyond a Joke: The Limits of Humour. Basingstoke: Palgrave-Macmillan.

Murata, K. (1994). Intrusive or co-operative? A Cross Cultural Study of Interruption. Journal of Pragmatics, 21(4), 385-400.

Osvaldsson, K. (2004). On Laughter and Disagreement in Multiparty Assessment Talk. Text, 24(4), 517-545.

Parker, I. (2013) Discourse Dynamics: Critical Analysis for Social and Individual Psychology (Psychology Revivals). London: Routledge.

Potter, J. (1988). What is reflexive about discourse analysis? - The case of reading readings.

In Woolgar, S. (Ed.), Knowledge and reflexivity: New frontiers in the sociology of knowledge (pp. 37-52). London: Sage.

Potter, J. (1996). Representing Reality - Discourse, Rhetoric and Social Construction. London: Sage.

Potter, J. (2003) Discursive Psychology: Between Method and Paradigm. Discourse \& Society, 14(6), 783-796.

Potter, J. (2010). Contemporary Discursive Psychology: Issues, Prospects, and Corcoran's Awkward Ontology. British Journal of Social Psychology, 49(4), 657-678. 
Potter, J. (2012). Re-reading Discourse and Social Psychology: Transforming Social Psychology. British Journal of Social Psychology, 51(3), 436-455.

Potter, J. \& Hepburn, A. (2010). Putting Aspiration into Words: 'Laugh Particles', Managing Descriptive Trouble and Modulating Action. Journal of Pragmatics, 42(6), 15431555.

Psathas, G. (1979), Everyday Languages: Studies in Ethnomethodology. New York: Irvington.

Romaniuk, T. (2009). The "Clinton Cackle”: Hillary Rodham Clinton's Laughter in News Interviews. Crossroads of Language, Interaction, and Culture, 7, 17-49.

Romaniuk, T. (2013). Interviewee Laughter and Disaffiliation in Broadcast News Interviews. In. Glenn, P. \& Holt, E. (Eds.), Studies of Laughter in Interaction (pp.201-220). London: Bloomsbury Publishing Plc.

Sacks, H. Schegloff, E.A. \& Jefferson, G. (1974). A Simplest Systematics for the Organization of Turn-taking for Conversations. Language, $50(4$ Part 1), 696-735.

Schegloff, E.A. (2000). Overlapping Talk and the Organization of Turn-taking for Conversation. Language in Society, 29(01), 1-63.

Schegloff, E.A. (2007). Sequence Organization in Interaction - A Primer in Conversation Analysis: Volume 1. Cambridge: Cambridge University Press.

Sert, O. \& Jacknick, C.M. (2015). Student Smiles and the Negotiation of Epistemics in L2 Classrooms. Journal of Pragmatics, 77, 97-112. 
Stevanovic, M. \& Peräkylä, A. (2012). Deontic Authority in Interaction: The Right to Announce, Propose, and Decide. Research on Language \& Social Interaction, 45(3), 297-321.

Ticca, A.C. (2013). Laughter in Bilingual Medical Interactions: Displaying Resistance to Doctor's Talk in a Mexican Village. In. Glenn, P. \& Holt, E. (Eds.), Studies of Laughter in Interaction (pp.107-129). London: Bloomsbury Publishing Plc.

Tileagă, C. (2010). Cautious Morality: Public Accountability, Moral Order and Accounting for a Conflict of Interest. Discourse Studies, 12(2), 223-239.

Tileagă, C. \& Stokoe, E. (2015). Discursive Psychology: Classic and Contemporary Issues. London: Routledge.

Weaver, S. (2015). The Rhetoric of Disparagement Humor: An Analysis of anti-Semitic Joking Online. HUMOR: International Journal of Humor Research, 28(2), 327-347.

Wodak, R. (2009) The Discourse of Politics in Action: Politics as Usual. London: Palgrave Macmillan. 